\title{
Identification of the Educational Problems at Higher Secondary Schools of Lahore
}

${ }^{a}$ Raheela Sarfraz, ${ }^{b}$ Sadaf Jabeen, ${ }^{c}$ Muhammad Ashraf Sajid, ${ }^{\text {d }}$ Muhammad Shahid Zulfiqar Ali

${ }^{a}$ Minhaj University Lahore, Pakistan

Email: raheelasarfraaz9@gmail.com

${ }^{\mathrm{b}}$ Assistant Professor, Lahore College for Women University, Lahore , Pakistan

Email: Sadaf.jabeen@lcwu.edu.pk

c PhD Scholar, University of Education, Lahore, Pakistan

Email: ashrafsajid59@yahoo.com

${ }^{d}$ PhD Scholar, University of Education, Lahore, Pakistan

Email:shahidzac@yahoo.com

\begin{tabular}{l}
\hline ARTICLE DETAILS \\
History: \\
Accepted 27 Nov 2020 \\
Available Online 31 Dec 2020
\end{tabular}

\section{Keywords:}

Education, Problems, Higher

Secondary Schools, Teachers'

Perceptions

JEL Classification:

$P_{36}$, F37, F39

DOI: $10.47067 /$ real.v3i3.85

\begin{abstract}
This study was conducted with the aim to find out educational problems faced by the teachers at higher secondary level by keeping in mind their most common issues regarding discipline, books, environment regarding teaching and learning, conduction of exams. This study was descriptive in nature and survey method was used to identify the higher secondary teachers' perceptions about educational problems that they faced. The sample has been selected while using the convenient sampling technique. The total 215 teachers were working in the boys' HSCs selected as the sample. On the other hand 282 female teachers have been selected for the study as a sample. The researcher collected the data while adapting the close ended questionnaire developed by (Ayub, 2014). There are 32 items included in the aforementioned research questionnaire. The descriptive statistics percentage and Mann Whitney $U$ test was applied by the researcher to analyze the data. In the light of findings of current study it is concluded that the educational problems exist at Higher Secondary schools Lahore. However, the teachers replied that they try to resolve the students' problem by discussing the issues with their colleagues, principals and most importantly with students as well. It was also concluded that there was no mean score difference in male and female teachers regarding the existence of problems faced at Higher Schools Lahore.
\end{abstract}

(C) 2020 The authors. Published by SPCRD Global Publishing. This is an open access article under the Creative Commons AttributionNonCommercial 4.0

Corresponding author's email address: raheelasarfraaz9@gmail.com

\section{Introduction}

Education implies bringing out of an individual's concealed potential with the goal that he can be grown socially as well as morally, in order to make him sensitive (individually and socially) (Durkheim, 2012). Individual gets certain types of skills in the result of knowledge that he/she gets from education, 
and becomes disciplined individual of the society (Ardashkin Igor, Martyushev Nikita, \& Bezborodov Valeriy, 2015). The responsibility for national development lies directly with education. Prosperity and growth of any nation majorly depends upon the educational institutions of that country. In order to make the progress possible, there is need to uplift the set standards for education system (Tatlah, 2015).

The better future of young generation is associated with their schooling. School education proves as baseline for the higher learning that is supposed to be essential in one's practical life (Borko, Jacobs, \& Koellner, 2010). The students' experiences that they receive in school life holds a unique position in their life (Peters, 2015). The students' whole learning that they acquire in colleges and universities depends upon their previous experiences (Alsubaie, 2016). They opt their professional carrier as per their aptitudes that developed in their schools life. The School education develops many basic concepts in students that proves to be beneficial in future life (Chilton, 2019). The educational institutions produce human resources. But unfortunately, Pakistan has still not recognized the education as the only means of developing the country and improving its human resources (Chishti, Tahirkheli, Raja, \& Khan, 2011).

The importance of uniformity in education system of the country is highlighted by the constitution of Pakistan. It implies that government is responsible regarding effective education system for all students without any discrimination (NEP, 2017). One of the basic pillar of the education system is school education. It provides a medium through which a child can learn with its full potential and capabilities. It is a gateway to higher education where simple to complex ideas culminate to its peak. At this stage, quality education should be ensured through proper assessment and monitoring. Studies showed that any child can perform to the full potential if right kind of environment and facilities are provided (Dahama, 2019).

Suleman, Hussain, Butt, and Ahmad (2012) highlighted some factors that become the reason of low standards of education at secondary level. That include facilities related to infrastructure, salaries of employees either teaching or administrative staff that is not sufficient in such era of inflation as majority of them not belong to well of families. Ghazi, Ali, Khan, Hussain, and Fatima (2010a) also mentioned some reasons of poor quality of education that were mismatch the enrollment rate of students and schools facilities, different standards of education use to gauge working parallel.

In Pakistan, there is a dearth of facilities and infrastructure, untrained and non-committed staff and lack of resources. School education standards in Pakistan need to be restructured and redesigned in the light of latest developments. The majority of public higher education funding goes to universities and is neglected by the universities. There is a wide network of higher education schools throughout Pakistan. Most schools provide intermediate education (higher grades XI-XII) in schools (Rashid \& Mukhtar, 2012). The Secondary School Directorate deals with curricula and other academic matters and the Intermediate and Secondary School Boards. Pakistan's high schools make students unprepared for university education. Such students remain significantly disadvantaged even after their degree from universities (Ishaq, 2016). The need of the hour is to figure out the basic problems which we are facing and then sort them out in a better way (Rashid \& Mukhtar, 2012). Taking into consideration the importance of education this study was conducted in order to identify educational problems at higher secondary schools.

Education makes a person adaptable to be adjusted in any circumstances as it broadens the mind and modify the behavior (Tatlah, 2015). But unfortunately, students face difficulties in attaining the education. The reasons behind these hurdles may vary depending upon the context or level of 
education. Therefore researcher conducted this study to highlight all those problems that teachers face at higher secondary schools.

\section{Methodology}

The researcher used the Quantitative approach to conduct the research as only quantitative data has been collected and analyzed while using the statistical procedure. The population for this research comprised of the total 28 HSCs of Lahore district. There were 9 HSCs for the boys whereas 19 for the girls. The teachers' strength in boys' higher secondary schools was 386 and 1072 in girls' higher secondary schools. The sample has been selected while using the convenient sampling technique. Total 10 HSCs were selected as a sample including 5 HSCs for boys as well as 5 HSCs for the girls. Whereas total 215 teachers were working in the boys' HSCs selected as the sample. On the other hand 282 female teachers have been selected for the study as a sample.

The researcher adapted the close ended questionnaire developed by (Ayub, 2014) for current study to measure the teachers' perceptions. There are 32 items included in the aforementioned research questionnaire under 4 factors including "discipline problems, availability of text books, conduct of exams and teachers' problems". The experts' opinion was taken for the validation of aforementioned research questionnaire. The reliability of the instruments was ensured after pilot testing it. There were 40 teacher and 40 students as participants other than the actual sample for the study whom the questionnaires were administered to. They were the representatives of males as well as female on 50/50 ratio. The outcome of Cronbach's Alpha against the questionnaire "Educational Problems of Higher Secondary Teachers (EPHST)” was o.81.

\section{Data Analysis}

The descriptive statistics percentage was used to identify the teachers' perspectives about the "Educational problems of Higher Secondary Schools of Lahore”. On the other hand, Mann Whitney U test was applied by the researcher to find out the difference among the teachers' perspectives on the basis of their gender.

Table 1: Demographic Information of Respondents

\begin{tabular}{|l|l|l|l|}
\hline \multicolumn{2}{|l|}{ Demographic variable } & Frequency & $\begin{array}{l}\text { Percentage } \\
\%\end{array}$ \\
\hline \multirow{2}{*}{ Gender } & Male teachers & 215 & 43.3 \\
\cline { 2 - 4 } & Female teachers & 282 & 56.7 \\
\hline
\end{tabular}

Result presented in the above table showed that there were 215 (43.3\%) male teacher and female teachers $282(56.7 \%)$ who responded on questionnaire. 
Table 2: Teachers' Response on Disciplinary Problems

\begin{tabular}{|c|c|c|c|c|c|c|}
\hline Sr \# & Statements & SD & DA & UD & A & SA \\
\hline 1 & $\begin{array}{l}\text { Teachers discuss with each other } \\
\text { to resolve students' group clashes }\end{array}$ & $10.7 \%$ & $6.2 \%$ & $12.7 \%$ & $40 \%$ & $30.4 \%$ \\
\hline 2 & $\begin{array}{l}\text { Teachers discuss with students to } \\
\text { resolve their group clashes }\end{array}$ & $11.7 \%$ & $6.4 \%$ & $9.3 \%$ & $32.2 \%$ & $40.4 \%$ \\
\hline 3 & $\begin{array}{l}\text { Teachers discuss } \\
\text { administration to resolve their } \\
\text { group clashes }\end{array}$ & $12.9 \%$ & $6 \%$ & $8.2 \%$ & $38.2 \%$ & $34.6 \%$ \\
\hline 4 & $\begin{array}{l}\text { Students' leadership attitude } \\
\text { promoted in schools with the help } \\
\text { of students' union. }\end{array}$ & $24.3 \%$ & $26.4 \%$ & $8 \%$ & $23.7 \%$ & $17.5 \%$ \\
\hline
\end{tabular}

Above mention table reflects the teachers' responses regarding disciplinary problems that they encountered in schools. In the response of first statement majority (70.4\%) of teachers replied that they "discuss about the students issue with the colleagues" and only $6.2 \%$ teachers were disagreed with this statement. Similarly, 72.6\% were agreed with "Teachers discuss with students to resolve their group clashes". In the same way majority (72.8\%) of teachers were agreed with "Teachers discuss with administration to resolve their group clashes". Contrarily, 50.7 \% teachers were disagreed with the statement that student leadership behavior was not promoted in their schools.

Table 3: Teachers' Response on Availability of Textbooks

\begin{tabular}{|c|c|c|c|c|c|c|}
\hline Sr. No & Statements & SD & DA & UD & A & SA \\
\hline 5 & $\begin{array}{l}\text { Textbooks are available on } \\
\text { cheap rates }\end{array}$ & $6.2 \%$ & $13.5 \%$ & $11.3 \%$ & $34 \%$ & $35 \%$ \\
\hline 6 & $\begin{array}{l}\text { Teacher timely complete the } \\
\text { syllabus }\end{array}$ & $18.5 \%$ & $9.7 \%$ & $10.9 \%$ & $29 \%$ & $32 \%$ \\
\hline 7 & $\begin{array}{l}\text { Teachers provide additional } \\
\text { learning material to } \\
\text { students }\end{array}$ & $20.1 \%$ & $21.7 \%$ & $38 \%$ & $11.9 \%$ & $8.2 \%$ \\
\hline 8 & $\begin{array}{l}\text { Curriculum at higher } \\
\text { secondary level is revised } \\
\text { periodically. }\end{array}$ & $13.5 \%$ & $7.2 \%$ & $10.3 \%$ & $35 \%$ & $34 \%$ \\
\hline 9 & $\begin{array}{l}\text { Teacher take part in the } \\
\text { curriculum revision }\end{array}$ & $29.6 \%$ & $26.6 \%$ & $28 \%$ & $7.6 \%$ & $8.2 \%$ \\
\hline 10 & $\begin{array}{l}\text { Students use helping books } \\
\text { in classrooms }\end{array}$ & $29.8 \%$ & $16.3 \%$ & $20.7 \%$ & $18.1 \%$ & $15.1 \%$ \\
\hline 11 & $\begin{array}{l}\text { Curriculum is in the } \\
\text { alignment of national goals }\end{array}$ & $6.8 \%$ & $4.2 \%$ & $9.7 \%$ & $30.4 \%$ & $48.9 \%$ \\
\hline
\end{tabular}

Teacher responses against the availability of textbooks reflected in the aforementioned table. In the response of first statement majority (69\%) of teachers replied that they were agreed that 
textbooks are available to the students on very affordable prices. Similarly, $61 \%$ teacher were agreed that they timely complete their syllabus. On the other hand, $41.8 \%$ teachers were disagreed whereas $38 \%$ teachers give response on undecided with the statement "Teachers provide additional learning material to students". Most of the teachers were agreed (69\%) that curriculum of higher secondary level is revised periodically. Opposing to the previously mention, most of the teachers (56.2\%) were disagreed that they don't take part in the process of curriculum revision. Similarly, many teacher (46.1\%) disagreed that their students do not use any kind of helping material in the classroom. Nevertheless great number of teachers $(79.3 \%)$ was agreed that present curriculum is in the alignment of goals of national educational and only $4.2 \%$ teachers disagreed with the same statement.

Table 4: Teachers' Response on Conduction of Exams

\begin{tabular}{|l|l|l|l|l|l|l|}
\hline Sr \# & Statements & SD & DA & UD & A & SA \\
\hline 12 & $\begin{array}{l}\text { Students sit at reasonable distance } \\
\text { during exams }\end{array}$ & $14.3 \%$ & $9.7 \%$ & $15.7 \%$ & $31.2 \%$ & $29.2 \%$ \\
\hline 13 & $\begin{array}{l}\text { Teachers properly invigilate during } \\
\text { exams }\end{array}$ & $26 \%$ & $15.5 \%$ & $30.2 \%$ & $15.9 \%$ & $12.5 \%$ \\
\hline 14 & Students face difficulty in cheating & $13.3 \%$ & $7.2 \%$ & $16.5 \%$ & $32.8 \%$ & $30.2 \%$ \\
\hline
\end{tabular}

The table shows the results of teachers' responses about the exams condition in the higher secondary schools. Majority (60.4\%) of teachers were agreed that during exams students sit at reasonable distance. But opposite to this, $41.5 \%$ teachers disagreed with "Teachers properly invigilate during exams". However, majority (63\%) of teachers were agreed that student faced difficulty in cheating.

Table 5: Teachers' Response on Problems that they face in Their Professional Life

\begin{tabular}{|c|c|c|c|c|c|c|}
\hline Sr. No & Statements & SD & DA & UD & A & SA \\
\hline 15 & $\begin{array}{l}\text { Additional reading material } \\
\text { is available to teachers. }\end{array}$ & $6.2 \%$ & $13.5 \%$ & $11.3 \%$ & $34 \%$ & $35 \%$ \\
\hline 16 & $\begin{array}{l}\text { Teacher guides are available } \\
\text { to teachers }\end{array}$ & $18.5 \%$ & $9.7 \%$ & $10.9 \%$ & $29 \%$ & $32 \%$ \\
\hline 17 & $\begin{array}{l}\text { Teachers have the } \\
\text { opportunity of in-services } \\
\text { training }\end{array}$ & $20.1 \%$ & $21.7 \%$ & $38 \%$ & $11.9 \%$ & $8.2 \%$ \\
\hline 18 & $\begin{array}{l}\text { Principal distribute } \\
\text { assignment among teachers } \\
\text { by considering teachers' } \\
\text { capabilities. }\end{array}$ & $13.5 \%$ & $7.2 \%$ & $10.3 \%$ & $35 \%$ & $34 \%$ \\
\hline 19 & $\begin{array}{l}\text { Teachers discuss issues with } \\
\text { principal to resolve the } \\
\text { problems }\end{array}$ & $29.6 \%$ & $26.6 \%$ & $28 \%$ & $7.6 \%$ & $8.2 \%$ \\
\hline
\end{tabular}




\begin{tabular}{|c|c|c|c|c|c|c|}
\hline 20 & $\begin{array}{l}\text { Principal discriminates } \\
\text { among teachers }\end{array}$ & $29.8 \%$ & $16.3 \%$ & $20.7 \%$ & $18.1 \%$ & $15.1 \%$ \\
\hline 21 & $\begin{array}{l}\text { Principal pleasant interact } \\
\text { with staff }\end{array}$ & $6.8 \%$ & $4.2 \%$ & $9.7 \%$ & $30.4 \%$ & $\begin{array}{l}48.9 \\
\%\end{array}$ \\
\hline 22 & $\begin{array}{l}\text { Principal visit classrooms to } \\
\text { check the teacher } \\
\text { performance }\end{array}$ & $12.3 \%$ & $9.5 \%$ & $14.9 \%$ & $27.4 \%$ & $36 \%$ \\
\hline 23 & $\begin{array}{l}\text { Principal give his/her } \\
\text { remarks to teachers } \\
\text { regarding class visit }\end{array}$ & $14.9 \%$ & $7.8 \%$ & $13.9 \%$ & $30.2 \%$ & $33.2 \%$ \\
\hline 24 & $\begin{array}{l}\text { Principal guide the staff } \\
\text { during working hours }\end{array}$ & $10.1 \%$ & $4 \%$ & $10.7 \%$ & $30.8 \%$ & $44.1 \%$ \\
\hline 25 & $\begin{array}{l}\text { Teachers perfume many } \\
\text { assignment along } \\
\text { teaching }\end{array}$ & $9.5 \%$ & $6.2 \%$ & $11.7 \%$ & $29 \%$ & $43.7 \%$ \\
\hline 26 & $\begin{array}{l}\text { Teachers timely receive } \\
\text { promotion. }\end{array}$ & $10.5 \%$ & $9.7 \%$ & $43.7 \%$ & $28.2 \%$ & $8 \%$ \\
\hline 27 & $\begin{array}{l}\text { Principal support teachers } \\
\text { up to maximum level }\end{array}$ & $14.1 \%$ & $10.1 \%$ & $16.9 \%$ & $31.2 \%$ & $27.8 \%$ \\
\hline 28 & $\begin{array}{l}\text { Teachers are friendly with } \\
\text { students }\end{array}$ & $14.9 \%$ & $6.8 \%$ & $11.3 \%$ & $27 \%$ & $40 \%$ \\
\hline 29 & $\begin{array}{l}\text { Teachers deliver lecture in } \\
\text { English. }\end{array}$ & $54.7 \%$ & $14.3 \%$ & $14.9 \%$ & $6.6 \%$ & $9 \cdot 5 \%$ \\
\hline 30 & $\begin{array}{l}\text { Teachers organized } \\
\text { seminars for students }\end{array}$ & $17.7 \%$ & $29.6 \%$ & $15.9 \%$ & $21.7 \%$ & $15.1 \%$ \\
\hline 31 & $\begin{array}{l}\text { Teachers are updated with } \\
\text { the latest information in } \\
\text { their relevant field }\end{array}$ & $15 \cdot 3 \%$ & $25.8 \%$ & $16.3 \%$ & $20.5 \%$ & $22.1 \%$ \\
\hline 32 & $\begin{array}{l}\text { Teachers are satisfied with } \\
\text { the transport facility }\end{array}$ & $17.5 \%$ & $34.4 \%$ & $16.1 \%$ & $19.5 \%$ & $9.5 \%$ \\
\hline
\end{tabular}

This table reflects the results of teachers' responses that they gave about the overall problems they face in their professional life in schools. Majority (69\%) of the teachers were agreed that they have additional reading material related to their subject area in schools. Similarly most of the teachers $(61 \%)$ were agreed that they have teachers' guide. But, most of the teachers responded as disagreed and undecided as their percentages were 41.8 and 38 respectively against the statement "Teachers have the opportunity of in-services training". In the same way, mostly teacher (69\%) were agreed with the statement "Principal distribute assignment among teachers by considering teachers' capabilities". Contrarily, most of the teachers $56.2 \%$ were strongly disagreed with "Teachers discuss issues with principal to resolve the problems. In the same pattern, many teachers $(46.1 \%)$ were disagreed with the statement "Principal discriminates among teachers". On the other hand, majority of teacher (79.3\%) 
were agreed that their principal interacted with in a pleasant mood. Similarly, majority (63.4\%) of the teachers were agreed that their principal has check on them as he/she visited while they were teaching in their classes. Likewise, most of the teachers (63.2\%) were agreed that their principals gave them remarks regarding the visit of classes. In the same way, majority of teachers $(74.8 \%)$ responded as agreed with the statement "Principal guide the staff during working hours" and only $4 \%$ teachers were disagreed. Similarly, a great of teachers (72.7\%) were agreed and only $6.2 \%$ teachers disagreed with the statement "Teachers perfume much assignment along with teaching”. Nevertheless, mostly teacher (43.7\%) was responded as undecided that teachers timely receive promotion. However, many teachers (59\%) were replied as agreed that their principal support them up to maximum level. In the same manner, majority of the teacher $(67 \%)$ were agreed that they were friendly with their students. But, a majority of respondents (69\%) disagreed with “Teachers deliver lecture in English”. Likewise, most of them $(47.3 \%)$ were disagreed that they organize seminars for their students. Similarly, many of them (41.1\%) were disagreed with statement "Teachers are updated with the latest information in their relevant field". In the same way many of them (51.9\%) were disagreed with "Teachers are satisfied with the transport facility".

Table 6: Comparison of teachers' responses on the bases of gender

\begin{tabular}{|l|l|l|l|l|}
\hline Gender & $\mathbf{N}$ & Mean & U & Sig. \\
\hline Male & 215 & 247.60 & -.189 & .850 \\
\hline Female & 282 & 250.66 & & \\
\hline
\end{tabular}

The table shows the results of Mann-Whitney $U$ test which was administered to find mean difference in female and male teachers' scores regarding the problems that they face in their schools. Results reflected that $\mathrm{U}=-1.89, \mathrm{p}>.05$, according to these value it was concluded that there was no mean score difference in male and female teachers responses. As mean value of male teachers responses was 247.60 that is almost equal to mean value of female teacher's responses that is 250.66 . It shows that teachers equally face problems in their schools.

\section{Conclusion}

In the light of findings of current study it is concluded that the educational problems exist at Higher Secondary schools Lahore. However, the teachers replied that they try to resolve the students' problem by discussing the issues with their colleagues, principals and most importantly with students as well. The teachers complete their syllabus well on time meanwhile they have to perform other tasks too assigned by the principals due to which they remained unable to give attention on individual needs of students. Similarly they pointed out that they are not the part of curriculum revision. The teachers further given their views that they were satisfied with the availability of books It was also concluded that there was no mean score difference in male and female teachers regarding the existence of problems faced at Higher Schools Lahore.

\section{Discussion}

This study was conducted to find out the teacher and students perceptions regarding educational problems at Lahore district. Findings of current study highlighted that teachers are not taking part in curriculum revision. Similar results were presented by Ali et al. (2017) in their study. According to them, while developing the curriculum, the experts did not include the inputs of teachers as well as subjects specialists. However, these results are contradictory to the finding of (Chilton, 2019; Rind et al., 2019) 


\section{Recommendation}

Keeping in mind the aforementioned findings following suggestions were made for future researchers:

- Comparative study may be carried out to identify the educational problems of (public and private) school students and teachers face.

- The teachers' workload should be rationalized by the authorities/ school heads that no teacher may be overburdened so he / she may be able to offer the duties well in manners.

\section{References}

Ali, N., Sharma, S., \& Zaman, A. (2017). School culture and school effectiveness: secondary schools in Pakistan. MOJEM: Malaysian Online Journal of Educational Management, 4(4), 50-65.

Alsubaie, M. A. (2016). Curriculum development: teacher involvement in curriculum development. Journal of Education and Practice, 7(9), 106-107.

Ardashkin Igor, B., Martyushev Nikita, V., \& Bezborodov Valeriy, P. (2015). Problem methodology as one of the ways of innovative organization of educational process. Procedia-Social and Behavioral Sciences, 166, 227-231.

Ayub, M. (2014). Educational crises at college level in Pakistan. Lahore: University of Education Lahore (Unpublished Doctoral Thesis).

Borko, H., Jacobs, J., \& Koellner, K. (2010). Contemporary approaches to teacher professional development. International encyclopedia of education, 7(2), 548-556.

Chilton, M. (2019). Technology in the classroom: Using video links to enable long distance experiential learning. Journal of Information Systems Education, 23(1), 51-55.

Chishti, S.-u.-H., Tahirkheli, S. A., Raja, S. A., \& Khan, S. B. (2011). Quality school education in pakistan: Challenges, successes and strategies. International Journal of Academic Research, 3(2), 972-976.

Dahama, O. P. (2019). Education and communication for development: Oxford and IBH Publishing.

Durkheim, E. (2012). Moral education. New York: Courier Corporation.

Ghazi, S. R., Ali, R., Khan, M. S., Hussain, S., \& Fatima, Z. T. (2010a). Causes of the decline of education in pakistan and its remedies. Journal of College Teaching \& Learning (TLC), 7(8), 9-16.

Ghazi, S. R., Ali, R., Khan, M. S., Hussain, S., \& Fatima, Z. T. (2010b). Causes of the decline of education in Pakistan and its remedies. Journal of College Teaching \& Learning (TLC), 7(8), 9-13.

Ishaq, M. (2016). Exploring New Dimensions in National Education Policies of Pakistan. (Doctoral Thesis), Sarhad University of Science and Information Technology, Peshawar.

NEP. (2017). National education policy (NEP). Retrieved from Ministry of Federal Education and Professional Training Government of Pakistan: https://planipolis.iiep.unesco.org/sites/planipolis/files/ressources/pakistan_national_education_policy_20 17-2025.pdf

Peters, R. S. (2015). Ethics and Education (Routledge Revivals). Oxford: Routledge.

Rashid, K., \& Mukhtar, S. (2012). Education in Pakistan: Problems and their solutions. International journal of academic research in business and social sciences, 2(11), 332-343.

Rind, I. A., Mari, M. A., Heidari-Shahreza, \& Ali, M. (2019). Analysing the impact of external examination on teaching and learning of English at the secondary level education. Cogent Education, 6(1), 1574947.

Suleman, Q., Hussain, I., Butt, M. N., \& Ahmad, S. (2012). Identification of the Problems Faced by Secondary School Teachers in Kohat Division, Pakistan. International Journal of Learning \& Development, 2(5), 324-340.

Tatlah, I. A. (2015). Effect of leadership behaviour and school organizational health on students' achievements. Lahore: (Unpublished Doctoral Thesis) University of Management and Sciences. 